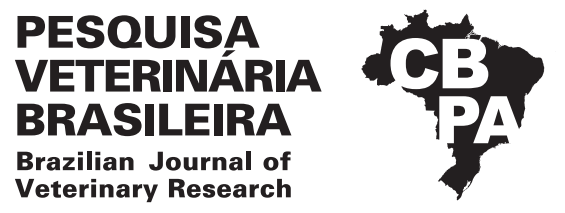

Pesq. Vet. Bras. 38(11):2088-2091, novembro 2018 DOI: $10.1590 / 1678-5150-P V B-5825$

Original Article

Animais de Produção/Livestock Diseases

ISSN 0100-736X (Print)

ISSN 1678-5150 (Online)

\title{
Skin burn and ocular damage by calcium oxide (virgin lime) in swines ${ }^{1}$
}

\author{
Juliana T.S.A. Macêdo ${ }^{2}$, Jair A. Ferreira Júnior², Karla A. Nascimento ${ }^{2}$, \\ Maira S.C. Lacerda ${ }^{2}$, Nathalia E.S. Pereira ${ }^{2}$ and Pedro M.O. Pedroso ${ }^{2 *}$
}

\begin{abstract}
Macêdo J.T.S.A., Ferreira Júnior J.A., Nascimento K.A., Lacerda M.S.C., Pereira N.E.S. \& Pedroso P.M.O. 2018. Skin burn and ocular damage by calcium oxide (virgin lime) in swines. Pesquisa Veterinária Brasileira 38(11):2088-2091. Laboratório de Patologia Veterinária, Fundação Universidade de Brasília, Campus Universitário Darcy Ribeiro, Via L4 Norte $s \backslash n$, Brasília, DF 70910-970, Brazil. E-mail: pedrosovet@yahoo.com.br

An outbreak of skin burn and ocular damage by calcium oxide in swines is reported. The outbreak occurred in a rural property located in the municipality of Iuiu, Western Bahia, during the transport of 60 pigs from a recreation farm to a fattening farm. The observed macroscopic lesions were erythematous areas; formation of papules, vesicles, and in some cases, there was the formation of firm, parched, high brown plaques and in other cases detachment and loss of skin. His eyes were dull. Histological analysis of the skin revealed areas of necrosis of focally extensive clotting of the epidermis, and dermis, delimited in the paniculus, by cellular debris and rare neutrophils. Corneal necrosis with perforated ulcer formation, superficial epithelial necrosis, edema, and neutrophil infiltration of the cornea adjacent to the ulcer were revealed in the eye.
\end{abstract}

INDEX TERMS: Skin, burn, ocular damage, calcium oxide, virgin lime, CaO, pigs, swine, clinics.

RESUMO-- [Queimadura de pele e lesão ocular por óxido de cálcio (cal virgem) em suínos.] Descreve-se um surto de queimadura de pele e lesão ocular por óxido de cálcio (cal virgem) em suínos. 0 surto ocorreu em uma propriedade rural localizada no município de Iuiu, região Oeste da Bahia, durante o transporte de 60 suínos de uma granja de recria para uma granja de engorda. Macroscopicamente foi evidenciado que na pele dos suínos havia áreas eritematosas, formação de pápulas, vesículas, e em alguns casos havia a formação de placas elevadas marrom firmes, ressequidas e em outros casos desprendimento e perda da pele. Os olhos estavam opacos. Na microscopia da pele observaram-se áreas de necrose de coagulação focalmente extensa da epiderme, e derme, delimitadas no panículo, por restos celulares e raros neutrófilos. No olho observou-se necrose da córnea com formação de úlcera perfurada, necrose do epitélio superficial, edema e infiltração de neutrófilos na córnea adjacente a úlcera.

TERMOS DE INDEXAÇÃO: Queimadura, pele, lesão ocular, óxido de cálcio, cal virgem, CaO, suíno, clínica.

\footnotetext{
${ }^{1}$ Received on May 3, 2018.

Accepted for publication on July 13, 2018.

${ }^{2}$ Laboratório de Patologia Veterinária, Fundação Universidade de Brasília (UnB), Campus Universitário Darcy Ribeiro, Via L4 Norte $s \backslash n$, Brasília, DF 70910-970, Brazil. *Corresponding author: pedrosovet@yahoo.com.br
}

\section{INTRODUCTION}

The chemical aggression to the skin can result from the local directly application or from the absorption of substances by the gastrointestinal tract, and from its subsequent distribution to the skin, resulting in contact dermatitis. The contact dermatitis may be subdivided in irritant and allergic contact dermatitis (Hargis \& Ginn 2009). The irritant contact dermatitis occurs more commonly, being defined as cutaneous reaction to an irritant concentration of the aggressor agent (Smith 2006). Most cases of contact dermatitis are caused by direct contact with substances, as corporeal or wound secretions, drugs application or exposure to acids, alkalis, soaps, detergents or irritant plants (Hargis \& Ginn 2009). The strong acids and bases produce lesion immediately after the contact and can be rightfully classified as chemical burns (Conceição \& Santos 2011). Calcium oxide (CaO), known as virgin lime or burnt lime, is a chemical compound used for several purposes. In livestock is commonly used to promote the disinfection of the animal's accommodations. When virgin lime gets mixed with water and perspiration, it becomes calcium hydroxide (Ca $(\mathrm{OH}) 2$ ), an alkaloid that exposed over the skin causes local irritation (Ng \& Koh 2011).

Clinical lesions include erythema, edema and vesiculation, that may progress to erosion, ulcerations, rind formation, 
and finally there is lichenification and hyperpigmentation (Smith 2006). In humans, among the chemical agents that cause ocular burns, the alkaline substances are more frequent and are responsible for serious sequelae to the ocular health (Moon \& Robertson 1983, Makino et al. 1999). The lesions by alkalis have as most frequent agents: ammonia (NH3), caustic soda $(\mathrm{NaOH})$, lime $(\mathrm{Ca}(\mathrm{OH}) 2)$, and potassium hydroxide $(\mathrm{KOH})$ (Morgan 1987). The objective of the present study is to characterize the cutaneous and ocular lesions by $(\mathrm{CaO})$ in swine.

\section{MATERIALS AND METHODS}

The outbreak occurred in a rural property located in the municipality of Iuiu (14²4'50" S, 4333'14" W), West region of Bahia, Brazil, during transportation of 60 swine from a recreation farm to a fattening farm. The clinical historic and epistemological data were obtained with the veterinarian that attended the cases. Seventeen pigs died spontaneously, and the remaining was slaughtered in stremis by the state inspection service. During the slaughter, skin fragments from 30 animals were collect, a tongue, an ocular globe, and fixed in $10 \%$ formalin, routinely processed for histology, imbibed in paraffin, cut 5 micrometers thick and stained by hematoxylin and eosin (HE).

\section{RESULTS}

The outbreak occurred in January 2014, affecting 60 swine of undefined race, of approximately $35 \mathrm{~kg}$ and 70 days of age. According to informations from the veterinarian, before the boarding, the truck body was washed and sprinkled with virgin lime for disinfection. Right after the swine boarding and due to the high temperature of the day, the driver proceeded with water sprinkling over the animals, assuming it would ease the heat. Immediately after this procedure, all animals presented agitated behavior, several were tossing, and after the skin presented reddish with vesicles and some with detachment of it. The eyes presented diffuse cornea opacity (Fig.1). Macroscopically, multifocal areas to blackened coalescent were observed in the face (burns). The dorsum region and lateral surface of the pelvic and thoracic limbs were diffusely blackened and lichenified, in addition to erythematous areas in the skin (axillae and groin) (Fig.2). There was formation of papules, vesicles, and in some cases the formation of elevated, firm, dry brown plaques (Fig.3), and in others cases the detachment and loss of skin. Skin microscopy showed areas of intense and diffuse clotting necrosis of the epidermis and dermis (Fig.4), delimited by cellular debris and rare neutrophils. In the eye was observed cornea necrosis with perforated ulcer formation, necrosis of the superficial epithelium, edema and infiltration of neutrophils in the cornea adjacent to the ulcer.

\section{DISCUSSION}

The diagnosis of skin burns and cornea ulcer by virgin lime in pigs was performed by the historic and clinical-pathological alterations. Reports of chemical burns associated to virgin lime are little described in animals (Cowart et al. 2000) In swine is reported an outbreak with high mortality (63.6\%) after exposure to the combination of hydrated lime and sodium bicarbonate (Cowart et al. 2000). In humans these accidents are frequent. The victims are usually of the male gender, young, and ordinarily with occurrence in the work or domestic place (Castellano et al. 2002). Epithelial necrosis

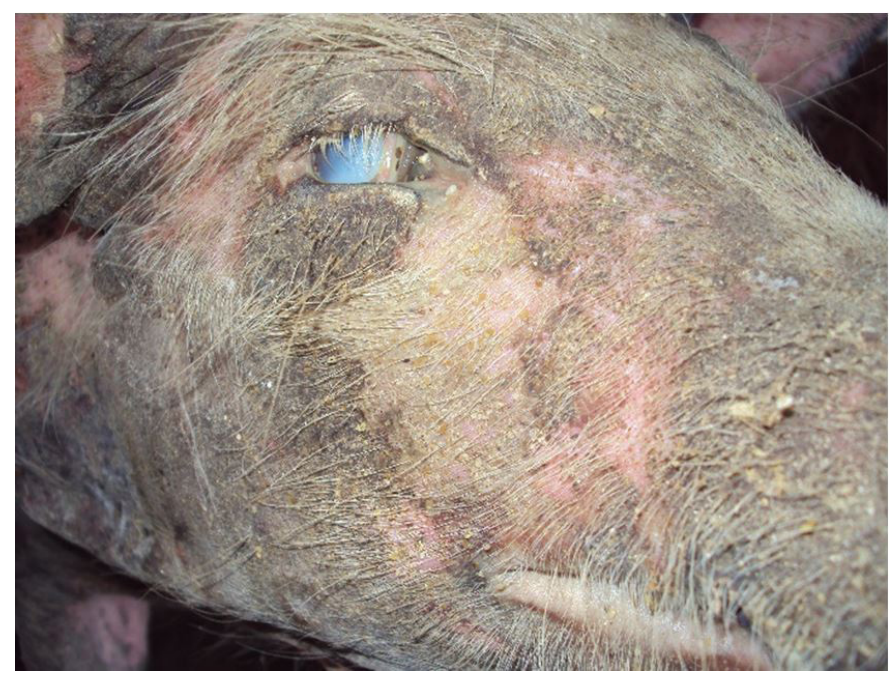

Fig.1. Ocular injury by calcium oxide in swine. Corneal opacity. Face with multifocal areas to blackened coalescent (burns) on the face.

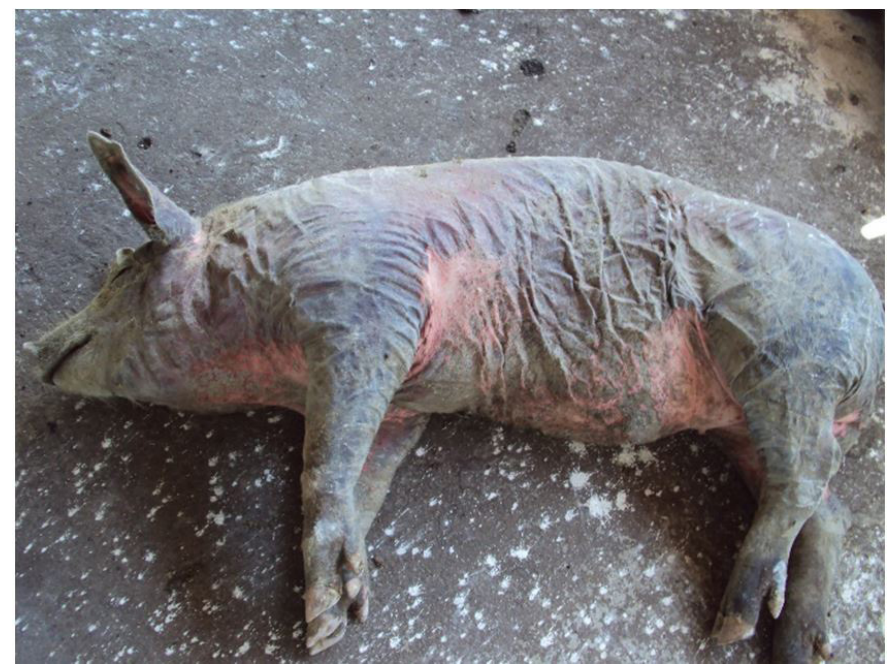

Fig.2. Skin burn by calcium oxide in swine. Dorsum and lateral surface of diffusely blackened and liquefied limbs. Erythematous areas on the skin (axillae and groin).

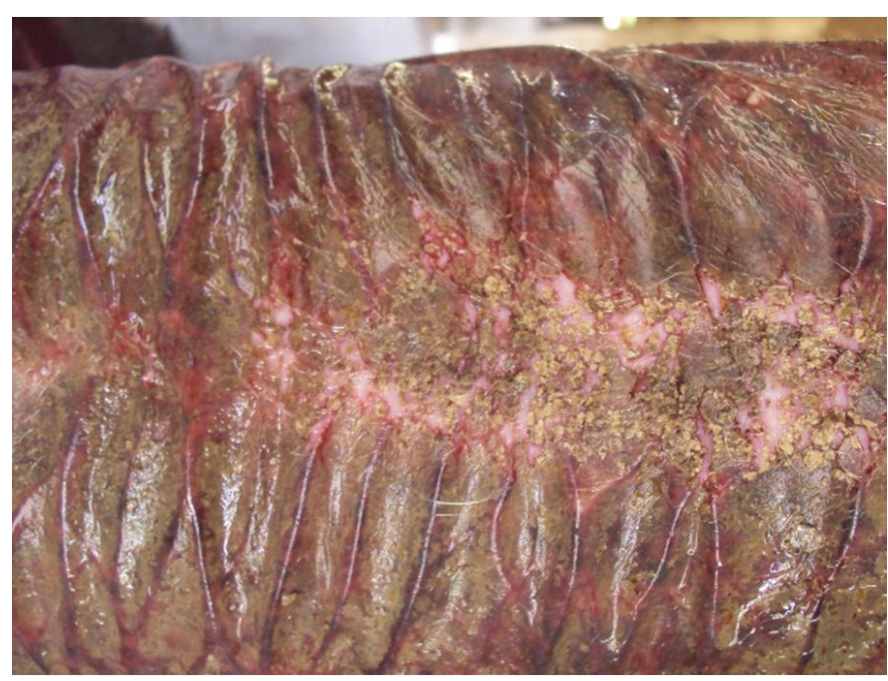

Fig.3. Skin burn by calcium oxide in swine. Dorsum region with formation of papules, vesicles and high firm, parched and brown plates. 


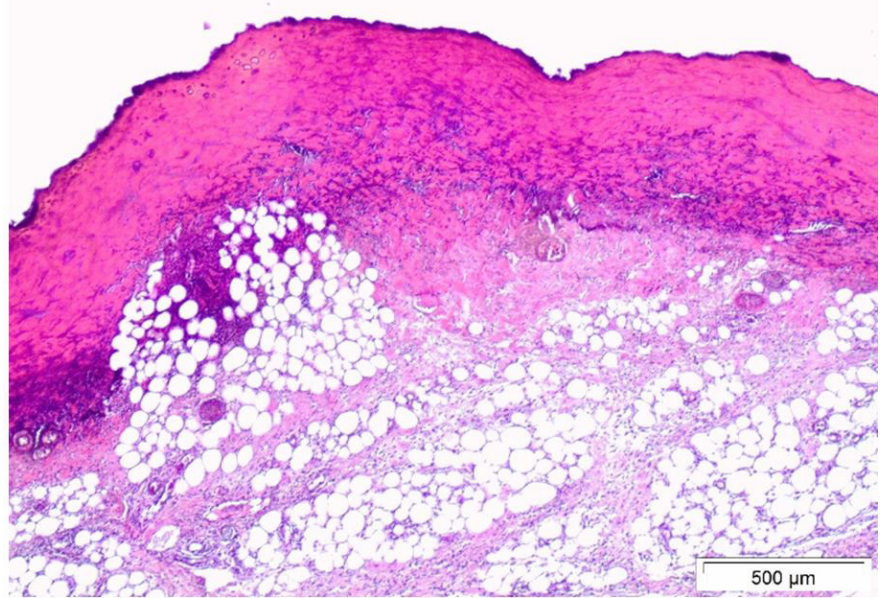

Fig.4. Skin burn by calcium oxide in swine. Areas of necrosis of intense and diffuse coagulation of the epidermis and dermis. HE, obj.10x.

occurs because the hydroxide anion saponifies fatty acids from cell membranes with resulting rupture and cell death, and cation is responsible for the free alkali (McCulley 1987, Freitas 1997). The cations react with the carboxyl groups of stromal collagens and glycosaminoglycans and the hydration of these, results in loss of transparency of the corneal stroma (Wagoner 1997).

Ocular irritation caused by disinfectants and insecticides inadvertently applied to the eye is not uncommon on farms. Chemical burns in the cornea and its attachments can have serious consequences, being the caused by alkalis more serious than the caused by acids. Corneal burns by acid tend to be acutely delimited rather than progressive, whereas alkaline burns cause progressive coagulation, dissolution, and detachment of the corneal stroma. Among the products used in disinfection of accommodations that frequently affect swine causing burns are caustic soda, virgin lime and hydrated lime, however, for its better use, one must have the appropriate knowledge in the manipulation of it to avoid accidents in humans and animals.

Both virgin lime and hydrated lime are used to paint maternity walls as a disinfection method or are scattered on the floor of the stall birthing as an aesthetic procedure in areas where piglets defecate in soft stools. When used the hydrated lime, the contact of it with water drinkers or urine produces an exothermic reaction with heat production capable of causing skin burns. When used virgin lime added with water, the formation of calcium hydroxide produces a highly alkaline suspension (pH 11-13) which does not stop the reaction immediately after drying. Thus, the biological activity of the product can maintain itself up to four days, period in which, when mixed with water, the reaction restarts and results in skin burns. In commercial farms, these problems tend to occur in the maternity causing lesions on the piglets' skin and on the mammary gland of matrices (Barcellos et al. 2007) Exceptionally, in this case, the event occurred in the transportation truck. The fact that swine have tossed explains the diffuse distribution of skin lesions, both by the action of heat and by the direct action of the irritating alkaline suspension in contact with the skin.
In the case of other differential diagnosis in domestic animals, allergic contact dermatitis (ACD) is added. Histological lesions such as vesicles, papules, spongiosis, edema and epidermal necrosis are variable, non-pathognomonic in both cases, and may be aggravated by self-trauma, being difficult to differentiate from ACD. On the other hand, lichenification, hyperpigmentation and alopecia are the result of chronic exposure to irritant agents (Gross et al. 2009, Mauldin \& Peters-Kennedy 2016). Thus, minimal inflammation with intense necrosis of the epidermis, lesion distribution and number of affected animals were important for the differential. This was justified by the hyperacute nature of the process, by the self-trauma and the restricted exposure of the swine to the irritant, the concentration of the product and the nature of the caustic. In addition, a case of fatal necrolytic dermatitis of irritant character in swine related to direct contact with urine and feces, hypothetically containing tiamulin or one of its metabolites, was verified in the literature after administration of the drug (Mauldin \& Peters-Kennedy 2016). However, there is no relation between the epidemiology and historic of the present outbreak with this antibiotic.

Burns in domestic animals are categorized as those that affect the partial or total thickness of the skin and the division is based on the depth of the lesion (Gross et al. 2009). Full thickness burns destroy all cutaneous structures and there is a lack of superficial blood supply and insensitivity to the touch. If full-thickness wounds cover more than 30 to 50 percent of the total surface area, then euthanasia should be considered (Rhodes 2014). In this case, because they were production animals, those animals that managed to reach the slaughterhouse were destined for emergency slaughter. Some animals died spontaneously, possibly due to the development of severe systemic shock. In severe burns, the release of inflammatory mediators may cause hemodynamic disturbances, including circulatory shock and ischemic reperfusion injury. Death can occur due to circulatory insufficiency or multiple organ failure. It is believed that multiple organ failure is the most common cause of death in patients with burns, even in the absence of uncontrolled infection (Cowart et al. 2000). Thus, the present outbreak represents an atypical condition of burn and cornea ulcer in swine, with serious lesions caused by the use of calcium oxide wet inadvertently.

\section{CONCLUSIONS}

It is recommended to avoid direct and prolonged contact of virgin lime or hydrated lime with the animals' skin to avoid irritation or possible burns.

The cases of strong alkali burns require continuous washing until the $\mathrm{pH}$ of the tissue returns to normal.

Neutralization of a chemical with an opposite weak acid is not recommended because the search for the neutralizing agent may delay immediate washing, and the neutralization reaction may be exothermic, causing further uncontrolled damage.

The importance of the history, clinical signs and the distribution of the lesions for the anatomopathological diagnosis of irritant contact dermatitis is also highlighted.

Acknowledgement: The authors thank the Veterinarian Zânder Fernandes Teixeira de Azevedo for the valuable help. 


\section{REFERENCES}

Barcellos D., Alberton G.C., Sobestiansky J., Donin D.G., Carvalho L.F.O.S. \& Morés N. 2007. Doenças da pele, p.500-501. In: Sobestiansky J. \& Barcellos D. (Eds), Doenças dos Suínos. Cânone Editorial, Goiânia.

Castellano A.G.D., Moreira H., Zago R.J. \& Milicovsky F.S. 2002. Avaliação epidemiológica dos pacientes vítimas de queimadura ocular pelo agente químico cal no Serviço de Oftalmologia do Hospital Universitário Evangélico de Curitiba. Arq. Bras. Oftalmol. 65(3):311-314. <http://dx.doi.org/10.1590/ S0004-27492002000300005>

Conceição L.G. \& Santos R.L. 2011. Sistema tegumentar, p.423-524. In: Santos R.L. \& Alessi A.C. (Eds), Patologia Veterinária. Roca, São Paulo.

Cowart R.P., Casteel S.W. \& Pace L.W. 2000. Dermal necrosis and mortality from alkali exposure in a group of finisher pigs. J. Swine Health Prod. 8(5):225-227.

Freitas D. 1997. Queimadura ocular, p.35-39. In: Moreira Júnior C.A., Freitas D. \& Kikuta H.S. (Eds), Trauma Ocular. Cultura Médica, Rio de Janeiro.

Gross T.L., Ihrke P.J., Walder E.J. \& Affolter V.K. 2009. Doenças de Pele do Cão e do Gato: diagnóstico clínico e histopatológico. 2ª ed. Roca, São Paulo, p.91-98.

Hargis A.M. \& Ginn P.E. 2009. 0 tegumento, p.1107-1261. In: McGavin M.D. \& Zachary J.F. (Eds), Bases da Patologia em Veterinária. 4ª ed. Mosby Elsevier, Rio de Janeiro.

Makino M.C.A., Reggi J.R.A., Waetge R.T., Dantas M.C.N. \& Dantas P.E.C. 1999. Perfil das queimaduras oculares na Santa Casa de São Paulo. Arq. Bras. Oftalmol. 62:472.
Mauldin E.A. \& Peters-Kennedy J. 2016. Integumentary system, p.566-567. In: Maxie M.G. (Ed), Jubb, Kennedy and Palmer's Pathology of the Domestic Animals. Vol.1. 6th ed. Elsevier, St Louis. <http://dx.doi.org/10.1016/ B978-0-7020-5317-7.00006-0>.

McCulley J.P. 1987. Chemical injuries, p.527-542. In: Smolin G. \& Thoft R.A (Eds), The Cornea: scientific foundation and clinical practice. 2nd ed. Little, Brown and Company, Boston.

Moon M.E. \& Robertson I.F. 1983. Retrospective study of alkali burns of the eye. Aust. J. Ophthalmol. 11(4):281-286. <http://dx.doi. org/10.1111/j.1442-9071.1983.tb01094.x><PMid:6421269>

Morgan S.J. 1987. Chemical burns of the eyes: cause and management. Brit. J. Ophthalmol.71(11):854-857.<http://dx.doi.org/10.1136/bjo.71.11.854> $<$ PMid:3689738>

Ng W.T. \& Koh D. 2011. Occupational contact dermatitis in manual cloud seeding operations. Singapore Med. J. 52(5):e85-87. <PMid:21633757>

Rhodes V.N.C. 2014. Dermatological emergencies. Vet. Nursing J.16(5):164167. <http://dx.doi.org/10.1080/17415349.2001.11013178>

Smith B.P. 2006. Medicina Interna de Grandes Animais. 3aㅡ ed. Malone, Barueri. 1728p.

Wagoner M.D. 1997. Chemical injuries of the eye: current concepts in pathophysiology and therapy. Surv. Ophthamol. 41(4):275-313. <http:// dx.doi.org/10.1016/S0039-6257(96)00007-0><PMid:9104767> 